\title{
High temperature-humidity index compromises sperm quality and fertility of Holstein bulls in temperate climates
}

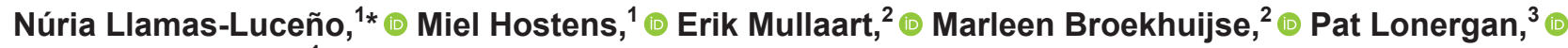 \\ and Ann Van Soom ${ }^{1 *}$ \\ ${ }^{1}$ Department of Reproduction, Obstetrics, and Herd Health, Faculty of Veterinary Medicine, Ghent University, 9820 Merelbeke, Belgium \\ ${ }^{2}$ CRV B.V., 6843 Arnhem, the Netherlands \\ ${ }^{3}$ School of Agriculture and Food Science, University College Dublin, Belfield, Dublin 4, Dublin D04 N2E5, Ireland
}

\begin{abstract}
Rising temperatures caused by climate change have adverse effects on cattle physiology, welfare, health, and reproduction. Heat stress in cows affects the oocyte and embryo directly through heat shock on cellular function. Fewer data are available on the effect of high temperatures on male fertility. Temperature-humidity index (THI) is a measure for assessing the risk of heat stress that combines the effects of temperature and humidity. The aim of this study was to determine the relationship between THI and fresh or frozen-thawed sperm quality of Holstein bulls kept in temperate climates. Bull sperm data of 29,170 ejaculates from 933 bulls collected at 3 Dutch artificial insemination centers between 2015 and 2018 were evaluated. The assessed variables included total sperm motility and morphology of fresh semen, and total sperm motility, morphology, and progressive motility of frozen semen 0 and $3 \mathrm{~h}$ after thawing. In addition, 56-d nonreturn rates were analyzed. The assessed effects were season and THI on the day of semen collection and during spermatogenesis (30 $\mathrm{d}$ before collection), bull, age of bull, year, and location. Bulls were divided into 2 categories according to their age: young $(<36 \mathrm{mo})$ and older $(>36 \mathrm{mo})$. Overall sperm quality of young bulls improved as age increased. No effect of THI on fresh sperm variables was observed in either young or older bulls. However, high THI at spermatogenesis negatively affected the cryotolerance of sperm cells. Sperm cells from young and older bulls showed a pronounced decrease (14-18\%) of the assessed variables $3 \mathrm{~h}$ after thawing after the increase of THI during spermatogenesis in autumn. Remarkably, older bulls were more sensitive to THI at spermatogenesis compared with semen collection, showing up to a 3.8 times higher negative effect on frozen sperm quality.
\end{abstract}

\footnotetext{
Received December 19, 2019.

Accepted May 7, 2020.

*Corresponding author: nuria.llamasluceno@ugent.be and ann. vansoom@ugent.be
}

However, an elevated THI at semen collection produced a tendency toward decreased 56-d nonreturn rates as the age of the bull increased. Although this decrease was up to $4 \%$, rising temperatures may still cause important economic losses in the future. For the first time, the present study confirmed that climate compromises not only sperm quality, but also dairy bull fertility.

Key words: sperm quality, bull fertility, climatic effect, heat stress

\section{INTRODUCTION}

For decades, the continuing rise in global temperatures has been a concern worldwide (Pachauri et al., 2007). According to the Environmental Data Compendium (2016), the annual average temperature in the Netherlands has increased by $1.7^{\circ} \mathrm{C}$ since 1906 , whereas global temperatures rose by $0.9^{\circ} \mathrm{C}$ on average (NASA, 2019). This increase in temperature in the Netherlands was not equally distributed across seasons, as summer temperatures have increased by $2.1^{\circ} \mathrm{C}$ during this period. Heat stress caused by elevated ambient temperature is particularly important for livestock breeders because it has been identified as a significant cause of subfertility (Hansen, 2009). The temperature-humidity index (THI), which accounts for the combined effects of environmental temperature and relative humidity, is commonly used to study the effect of heat stress and determine the thermal comfort zone in cows (Armstrong, 1994; Mader et al., 2006; Dikmen and Hansen, 2009). However, few studies have determined the physiological effect of THI on bull fertility (Wettemann and Boehmer, 2014; Menegassi et al., 2016; Romanello et al., 2018).

Several studies have highlighted the detrimental effects of high temperatures on bovine semen quality. Negative effects of heat exposure were observed in semen collected between 14 and $42 \mathrm{~d}$ after artificial scrotal insulation, indicating that heat stress is more prejudicial for developing germ cells than for mature spermatozoa (Rahman et al., 2011). Artificially con- 
trolled short-term exposure to heat stress has been reported to increase respiratory rate, rectal temperature, and water consumption of bulls (Meyerhoeffer et al., 1985), to disrupt spermatogenesis, decrease sperm viability and motility, and increase the likelihood of reduction of testicular weight and alteration of testosterone levels, as observed in other mammals (Sailer et al., 1997; Setchell, 1998; Alves et al., 2016). In all of these studies, sperm quality returned to normal 6 to 8 wk after heat stress exposure.

Seasonal effects on bovine semen quality have been previously studied with contradictory outcomes (Brito et al., 2002b; Malama et al., 2017; Sabés-Alsina et al., 2017), perhaps because the effect of season can vary greatly among climatic zones. As such, THI may be a more comprehensive indicator of environmental conditions because it combines temperature and humidity and has a notable effect on dairy cows, with a value of 68 indicating a comfort threshold value and values greater than 75 indicating severe heat stress (De Rensis et al., 2015; Herbut and Angrecka, 2018).

Another factor that influences semen quality is the bull's age (Brito et al., 2002a; Murphy et al., 2018). With the advent of genomic selection, genetically elite young bulls can be identified at a very young age (Goddard and Hayes, 2007; Schefers and Weigel, 2012). However, the semen quality of such young bulls may exhibit significant variation due to the range of the age at which puberty is reached (Barth et al., 2008).

Although several studies have assessed seasonal effects on semen quality, few have used a metric that can be used across different climatic zones or with a large number of bulls. Moreover, some studies focused only on the meteorological conditions at collection time, ignoring the potential deleterious effect that high temperatures can have during spermatogenesis. In addition, determining frozen semen quality $3 \mathrm{~h}$ after thawing can help to understand the quality and survival of sperm cells after AI. Furthermore, to our knowledge, no studies have been published on the influence of variation in THI on bull fertility, as assessed by subsequent nonreturn rates (NRR). Therefore, in this study, we aimed to identify the effects of THI, season, and age on semen quality and fertility in Holstein bulls located in the Netherlands and to contribute to a better understanding of the effect of climate factors on reproductive efficiency.

\section{MATERIALS AND METHODS}

\section{Meteorological Characteristics in the Netherlands}

The climate of the Netherlands is classified as marine west coast climate, according to Köppen classification
(Köppen, 1931), characterized by stable climates with few temperature extremes and abundant precipitation in all months. Due to the size and geography of the country, little variation in climate is observed from region to region, although the marine influences are less inland. Summers are moderately warm, with average temperatures ranging from 10.5 to $22.8^{\circ} \mathrm{C}$, and winters are cool, with average temperatures ranging from 0.2 to $6.4^{\circ} \mathrm{C}$. Days with a maximum temperature $>20^{\circ} \mathrm{C}$ often occur in April through October, whereas days $>25^{\circ} \mathrm{C}$ often occur in May until September. Last, days $>30^{\circ} \mathrm{C}$ are rare and usually found only in June through August. Annual temperature ranges from 10 to $15^{\circ} \mathrm{C}$ and annual precipitation accumulations generally range from 50 to $250 \mathrm{~cm}$. This climate is typically highly humid, with a relative humidity average of $82 \%$, and an average of precipitation of $184 \mathrm{~d} / \mathrm{yr}$. Moreover, the number of daylight hours varies between almost 8 and almost 17 h (KNMI, 2018; climate data for De Bilt 1981-2010).

During the period of semen collection for this experiment, the average temperature was $10.4^{\circ} \mathrm{C}$, whereas the maximum and minimum were 14.7 and $5.9^{\circ} \mathrm{C}$, respectively. The average relative humidity was $80.8 \%$, whereas the maximum and minimum were 94.9 and $62.7 \%$, respectively. The daily precipitation average was 2.43 $\mathrm{mm}$, the average of daily maximum wind speed was $36.8 \mathrm{~m} / \mathrm{s}$, and the daily global radiation average was 1,010.2 J/ $\mathrm{cm}^{2}$ (KNMI, 2018; climate data for Deelen 2012-2018).

However, it is expected that these meteorological characteristics will vary as Western Europe is warming considerably faster than climate change models predicted (van Oldenborgh et al., 2009).

\section{Breeding Premises and Animals}

Black and Red Holstein-Friesian dairy bulls $(\mathrm{n}=933$, mean \pm SEM; $30.45 \pm 0.152$ mo old; Supplemental Table S1, https://doi.org/10.3168/jds.2019-18089) were maintained at CRV AI Centre (CRV B.V., Arnhem, the Netherlands), received uniform feeding, and were housed indoors in one of 3 collection barns in the Netherlands: BE (latitude 51.725990 and longitude 5.825880), HA (latitude 52.207400 and longitude 6.297850), and GK (latitude 53.241960 and longitude 5.893440). Until 2017 , the barns were naturally ventilated without any mechanical support, but after renovations in 2017, the barns were provided with mechanical ventilation (ventilation for controlled air inlet and outlet, overpressure system). To accommodate this difference, the variable "year" was included in the statistical model. Ejaculates were collected with an artificial vagina and diluted 1:1 using an animal protein-free extender (OPTIXcell; 
IMV Technologies, L'Aigle, France) and then were transported to the central laboratory. The transportation time between the last collected ejaculate and the semen analysis was between $30 \mathrm{~min}$ and $2 \mathrm{~h}$, due to the different distances between the laboratory and the collection sites. During that time frame, the ejaculates remained in temperature-controlled transport boxes.

\section{Semen Processing and Computer-Assisted Sperm Analysis}

All ejaculates were analyzed for sperm quality (total and progressive motility, morphology) using a computer-assisted sperm analysis (CASA) system for sperm quality assessment of 2 pooled straws per ejaculate (IVOS II, Hamilton Thorne Ltd., Beverly, MA) that automatically added the information for each ejaculate to the CRV database. With an automated stage, 8 microscope fields were analyzed using the predetermined starting position within each chamber of a standardized 4-chamber Leja counting slide (Leja Products B.V., Nieuw-Vennep, the Netherlands). Statistical analyses were performed on the basis of the mean of these 8 fields.

A total of 30 frames were captured at 60 frames/s with software settings as follows: cell detection minimum contrast $=8 ;$ minimum cell size $=5$ pixels; cell intensity $=70$. The cutoff value for progressive cells was $50 \mu \mathrm{m} / \mathrm{s}$ for average path velocity and $70.0 \%$ for straightness; slow cells were recorded as static and had an average path velocity cutoff of $30.0 \mu \mathrm{m} / \mathrm{s}$ and a straight line velocity cutoff of $15.0 \mu \mathrm{m} / \mathrm{s}$. The temperature of the heated microscope stage was $37^{\circ} \mathrm{C}$. Morphologic abnormalities were assessed with the CASA system. The IVOS II CASA system allowed the monitoring and recording of 5 categories of abnormalities: bent and coiled tails (\%), distal and proximal droplets $(\%)$, distal midpiece reflex (\%), and morphologically normal sperm (\%). The measurement settings were as follows: illumination led intensity $=2,202$; distal midpiece reflex droplet to tail end $\max =5$; tail length $\max =20$; droplet distal distance minimum $=5$; droplet proximal head length $=15$; elongation maximum $=79$ and minimum $=1$; head brightness minimum $=$ 165; head size maximum $=70$ and minimum $=12$; tail bend angle averaging length $=5$; tail bending angle rate minimum $=20$; tail brightness minimum $=80$; tail coiled angle minimum $=180$.

Only fresh semen samples with normal morphology ( $\geq 70 \%$ normal) were processed according to the company's routine practice. The 1:1 diluted ejaculate was diluted to its final commercial concentration, varying between 15 and 20 million cells per straw, using an animal protein-free extender (OPTIXcell; IMV Technolo- gies). Mini straws (IMV Technologies) were printed and filled with the extended semen samples and cooled to $5^{\circ} \mathrm{C}$ in a cooling cabinet for 2 to $4 \mathrm{~h}$ before cryopreservation. A programmable freezing machine, DigitCool (IMV Technologies), was used to gradually cool the semen straws from $5^{\circ} \mathrm{C}$ to $-140^{\circ} \mathrm{C}$, which were then submerged and stored in liquid nitrogen at $-196^{\circ} \mathrm{C}$ until use. After the freezing process was complete, 2 straws were thawed and analyzed using the CASA system. The analysis included total and progressive motility, morphology and concentration of motile cells immediately and $3 \mathrm{~h}$ after thawing (stress test, storing the semen at $37^{\circ} \mathrm{C}$ ). Only those straws with post-thaw motility $\geq 30 \%$ were retained.

\section{Field Fertility}

The retained straws were commercially available and distributed worldwide. Straws were assessed retrospectively, and only inseminations done on cows in natural estrus and by trained inseminators of CRV were used in the analysis. Fertility was defined as NRR $56 \mathrm{~d}$ after insemination (NRR56\%) on the basis of insemination records with a minimum of 100 inseminations per individual charge of semen; once a cow was bred for the first time, successful first insemination and pregnancy were assumed if no subsequent breeding record was observed within the following 56-d period (i.e., 2 normal estrous cycles). Because each ejaculate produced many straws, multiple fertility results were obtained for each batch. For the statistical approach, insemination data (0 or 1$)$ were first adjusted for herd- and cow-related variables. The NRR56\% results were corrected for the following variables: herd-year-season (interaction parameter), AI technician, month of insemination, parity, day of the week of insemination, interval between calving and insemination, milk production of the inseminated cow, uterine tone score $(0-1$; contraction status of uterus), pipette score ( $0-1$; cleanliness of pipette), effect of AI technician (12-mo average), and estimated breeding value for NRR56\% of the cow (NRR56 model; CRV B.V.).

\section{Environmental Factors}

The Royal Netherlands Meteorological Institute provided historical weather data containing relative humidity (\%) and temperature $\left({ }^{\circ} \mathrm{C}\right)$ per hour, as well as the temperature and relative humidity data obtained from 3 weather stations near the barns (approximately at $16.7 \mathrm{~km}$ from location $\mathrm{BE}, 37.7 \mathrm{~km}$ from $\mathrm{HA}$, and 9.4 $\mathrm{km}$ from GK). Consequently, the THI was calculated per hour, and the maximum THI for each day was used for the analysis as the highest daily value. 
Two THI values were associated with each ejaculate, 1 corresponding to the day of semen collection and 1 during spermatogenesis. As lower sperm quality was reported between 14 and $42 \mathrm{~d}$ after artificial scrotal insulation (Rahman et al., 2011); we included the THI that corresponded to $30 \mathrm{~d}$ before the ejaculate was collected. The following equation was used to calculate the THI (Thom, 1959, García-Ispierto et al., 2007), where $T$ is the temperature in ${ }^{\circ} \mathrm{C}$ and $R H$ is relative humidity $(\%)$ :

$$
\mathrm{THI}=0.8 \times T+(R H / 100) \times(T-14.4)+46.4 .
$$

Meteorological seasons, defined as groups of 3 mo based on the annual temperature cycle, were also added to the data set, as our aim was to study the effect of the meteorological conditions on the fertility of bulls. The beginning of spring was defined as starting on March 1, summer on June 1, autumn on September 1, and winter on December 1.

Similar to the THI, 2 seasons were associated with each ejaculate: the season corresponding to the day of semen collection and the season corresponding to the day when the sperm cells from the ejaculate were at meiosis phase of spermatogenesis (30 d before).

\section{Statistical Analysis}

The outcome variables assessed included total motility and normal morphology of fresh semen, total motility and progressive motility, normal morphology of frozenthawed semen recorded immediately $(0 \mathrm{~h})$ and $3 \mathrm{~h}$ after thawing, and NRR56\%. All variables were expressed as percentages. From January 1, 2015, total motility at 0 $\mathrm{h}$ was determined using the CASA system. Before that date it was subjectively evaluated, and therefore not included in the study. For this reason, data recording of total motility at $0 \mathrm{~h}$ started on January 1, 2015, and continued until July 5, 2018. The remaining measurements assessed with the CASA system were introduced to the laboratory routine and recorded from 2016 until 2018. Data recording of NRR $56 \%$ started on October 1, 2012, and continued until July 5, 2018. The total number of records in the database was 29,170, with 933 bulls. Animal data were checked for entry errors and reformatted if necessary, according to the original records. Moreover, not all of the entries contained information for all of the variables. Therefore, the total number of records were the following: fresh total motility $=5,645$ (116 bulls); fresh normal morphology $=$ 5,642 (116 bulls); total motility at $0 \mathrm{~h}=15,855$ (437 bulls); total motility at $3 \mathrm{~h}=9,364$ (253 bulls); progressive motility at $0 \mathrm{~h}=9,373$ (253 bulls); progressive motility at $3 \mathrm{~h}=9,364$ (253 bulls); normal morphology at $0 \mathrm{~h}=9,373$ (253 bulls); normal morphology at $3 \mathrm{~h}=$ 9,365 (253 bulls); and NRR56\% with a minimum of 100 inseminations $=6,422(523$ bulls; Supplemental Table S1, https://doi.org/10.3168/jds.2019-18089). Season and THI data were linked to the ejaculate data that matched the ejaculate collection date and the meiotic phase of spermatogenesis.

All statistical analyses were performed using $\mathrm{R}(\mathrm{R}$ Core Team, 2013). First, descriptive statistics were calculated using the base package to describe the population, and histograms were created to explore the nature of the data. These variables included the bull age (months) at the time of semen collection, location, and individual bull.

The age of the bull and the THI were used as covariates after re-scaling to a mean of 0 and standard deviation of 1. Categorical variables included season, location, and year. Separate models were built for each outcome variable. Depending on the outcome variable, normal and Poisson generalized mixed models were built using the lme4 package (Bates et al., 2015). First, baseline models were compared with a multilevel model using bull as a random effect. Next, full models were created and backward elimination of each of the covariates was tested with the drop1 function using Akaike's information criterion (smaller best fit). All of the effects that were found to significantly improve the model fit were used in the final model. Final model coefficients for continuous and least squares means for categorical variables were reported. Biologically relevant interactions were introduced and explored by creating effect plots using the effects package.

\section{RESULTS AND DISCUSSION}

Descriptive statistics of the distribution by age of the bull when the ejaculates were collected showed a clear distinction between young and older bulls (Supplemental Figure S1, https://doi.org/10.3168/jds.2019-18089). Therefore, the samples were divided into 2 groups: young bulls $(<36 \mathrm{mo})$ and older bulls ( $\geq 36 \mathrm{mo}$; Supplemental Figure S1). The random effect of individual bull was significant in each of the models (Supplemental Tables S2 and S3, https://doi.org/10.3168/jds.2019 -18089) for all of the variables in young and older bulls; hence, the multilevel models were retained.

\section{Seasonal Effect on Sperm Characteristics}

Total motility and normal morphology of fresh sperm from young bulls was higher $(P<0.001)$ when spermatogenesis occurred in summer compared with other seasons (Table 1$)$. Moreover, differences $(P<0.01)$ in total motility $0 \mathrm{~h}$ after thawing the sperm were observed 
Table 1. Percentage of total motility and normal morphology of fresh sperm, total motility, progressive motility, normal morphology of frozen sperm 0 and $3 \mathrm{~h}$ after thawing, and 56-d nonreturn rate after AI with semen from young ( $<36$ mo old) dairy bulls at different seasons

\begin{tabular}{|c|c|c|c|c|c|c|c|c|}
\hline \multirow[b]{2}{*}{ Item } & \multirow[b]{2}{*}{ Time } & \multicolumn{4}{|c|}{ Season $^{1}$} & \multicolumn{3}{|c|}{$P$-value ${ }^{2}$} \\
\hline & & Winter & Spring & Summer & Autumn & Season & $\begin{array}{c}\text { Season } \\
\times \text { age }\end{array}$ & $\begin{array}{r}\text { Season } \\
\times \text { THI }\end{array}$ \\
\hline \multirow[t]{2}{*}{ Fresh total motility, $\%$} & Spg & $83.7 \pm 1.1^{\mathrm{c}}$ & $85.8 \pm 0.9^{\mathrm{b}}$ & $89.6 \pm 1.4^{\mathrm{a}}$ & $83.2 \pm 1.0^{\mathrm{c}}$ & $* * *$ & $* * *$ & * \\
\hline & $\mathrm{Col}$ & $84.9 \pm 1.0^{\mathrm{a}}$ & $84.7 \pm 0.9^{\mathrm{a}}$ & $85.3 \pm 1.0^{\mathrm{a}}$ & $83.3 \pm 1.0^{\mathrm{b}}$ & $* * *$ & $* * *$ & NS \\
\hline \multirow{2}{*}{ Fresh normal morphology, \% } & Spg & $92.9 \pm 0.6^{\mathrm{c}}$ & $94.4 \pm 0.5^{\mathrm{b}}$ & $96.8 \pm 0.7^{\mathrm{a}}$ & $93.0 \pm 0.5^{\mathrm{c}}$ & $* * *$ & $* * *$ & $* * *$ \\
\hline & $\mathrm{Col}$ & $93.3 \pm 0.6^{\mathrm{a}}$ & $93.4 \pm 0.5^{\mathrm{a}}$ & $93.6 \pm 0.5^{\mathrm{a}}$ & $92.5 \pm 0.5^{\mathrm{b}}$ & *** & $* * *$ & NS \\
\hline \multirow[t]{2}{*}{ Total motility $3 \mathrm{~h}, \%$} & Spg & $42.5 \pm 0.7^{\mathrm{ab}}$ & $42.4 \pm 0.6^{\mathrm{b}}$ & $43.8 \pm 0.6^{\mathrm{a}}$ & $41.7 \pm 0.6^{\mathrm{b}}$ & $* * *$ & $* *$ & $*$ \\
\hline & $\mathrm{Col}$ & $43.7 \pm 0.7^{\mathrm{a}}$ & $42.6 \pm 0.6^{\mathrm{a}}$ & $42.6 \pm 0.6^{\mathrm{a}}$ & $41.3 \pm 0.6^{\mathrm{b}}$ & $* * *$ & NS & NS \\
\hline \multirow[t]{2}{*}{ Progressive motility $0 \mathrm{~h}, \%$} & Spg & $45.9 \pm 0.5^{\mathrm{b}}$ & $47.1 \pm 0.5^{\mathrm{a}}$ & $46.8 \pm 0.5^{\mathrm{ab}}$ & $46.2 \pm 0.5^{\mathrm{ab}}$ & $* *$ & $* *$ & NS \\
\hline & $\mathrm{Col}$ & $45.9 \pm 0.5^{\mathrm{b}}$ & $46.8 \pm 0.5^{\mathrm{a}}$ & $46.6 \pm 0.5^{\mathrm{ab}}$ & $46.4 \pm 0.5^{\mathrm{ab}}$ & $\dagger$ & NS & NS \\
\hline \multirow[t]{2}{*}{ Progressive motility $3 \mathrm{~h}, \%$} & Spg & $36.1 \pm 0.6^{\mathrm{ab}}$ & $35.7 \pm 0.5^{\mathrm{ab}}$ & $36.9 \pm 0.6^{\mathrm{a}}$ & $35.6 \pm 0.6^{\mathrm{b}}$ & $* *$ & $* *$ & $*$ \\
\hline & $\mathrm{Col}$ & $37.1 \pm 0.6^{\mathrm{a}}$ & $35.8 \pm 0.5^{\mathrm{b}}$ & $35.9 \pm 0.6^{\mathrm{ab}}$ & $35.4 \pm 0.6^{\mathrm{b}}$ & $* * *$ & NS & NS \\
\hline Normal morphology 0 h, $\%$ & $\mathrm{Spg}$ & $-^{3}$ & - & - & - & NS & NS & NS \\
\hline 56 -d nonreturn rate, $\%$ & $\mathrm{Col}$ & - & - & - & - & NS & NS & NS \\
\hline
\end{tabular}

${ }^{\mathrm{a}-\mathrm{c}}$ Values with different superscripts in the same row are significantly different $(P \leq 0.05)$.

${ }^{1} \mathrm{LSM} \pm \mathrm{SEM}$ of each season for all of the variables at semen spermatogenesis (Spg) and collection (Col) time.

${ }^{2} P$-values of the effect of season and the interactions between season and age of the bull (months), and season and temperature-humidity index (THI) for all of the variables at semen spermatogenesis and collection time.

${ }^{3}$ No significant differences between different seasons; therefore, season was not included in the model.

$0 \leq * * * \leq 0.001<* * \leq 0.01<* \leq 0.05<\dagger \leq 0.1<\mathrm{NS} \leq 1$.

between seasons; the lowest percentage was observed when spermatogenesis occurred in winter $(51.9 \pm 0.5)$ and the highest in summer $(56.9 \pm 0.5)$. However, $3 \mathrm{~h}$ after thawing, no differences between seasons were observed in total motility, progressive motility, or normal sperm morphology of young bulls. Minor differences between seasons were observed in progressive motility and normal morphology of frozen-thawed sperm.

In older bulls, minor differences in total motility of fresh sperm were observed between the seasons when spermatogenesis occurred (Table 2). Similar to the ejaculates from young bulls, total motility of frozen sperm immediately after thawing was highest when spermatogenesis occurred in summer $(56.7 \pm 0.9)$ compared with other seasons ( $53.8 \pm 0.7$ in autumn, 53.4 \pm 0.7 in winter, and $51.7 \pm 0.6$ in spring), indicating that the sperm cells that were at meiosis in the summer had a slightly better survival after cryopreservation. However, no differences between seasons were observed in progressive motility and morphology. Moreover, $3 \mathrm{~h}$ after thawing, minor differences between seasons were observed for all of the assessed outcome variables. As a consequence, the season when spermatogenesis occurred had no effect on the NRR $56 \%$ of young or older bulls. Our findings agree with another study in Norway, where no differences were observed in the NRR $56 \%$ of semen collected at different seasons; however, calving rate was significantly higher for semen collected from December to March (Haugan et al., 2005). The calving rate is defined as the number of calves produced divided by the number of inseminated cows (Wilkanowska and Kokoszyński, 2015). The observed difference is explained by the potential margin of error in NRR $56 \%$ compared with calving rates when assessing cattle fertility.

When assessing the seasonal effect at the time of semen collection, subtle differences were observed between young and older bulls (Tables 1 and 2). Both young and older bulls had lower $(P<0.001)$ total motility, progressive motility, and normal morphology $3 \mathrm{~h}$ after thawing when semen collection occurred in autumn. However, similar to a recent study in Ireland, the differences between seasons were relatively small and, although statistically significant, might not be biologically meaningful or have a commercial impact (Murphy et al., 2018). This result could be explained by the selection of raw semen for further processing, with a cutoff of $<70 \%$ normal morphology. Most likely, the ejaculates with detrimental effects from the season were not processed due to the strict standards for quality control.

No effect of the semen collection season was observed on NRR $56 \%$. In contrast to our findings, Malama et al. (2017) observed an improvement in the percentage of total motile, progressively motile, and rapidly motile 
Table 2. Percentage of total motility, normal morphology of fresh sperm, total motility, progressive motility, normal morphology of frozen sperm 0 and $3 \mathrm{~h}$ after thawing, and nonreturn rate $56 \mathrm{~d}$ after AI with semen from older ( $\geq 36$ mo old) dairy bulls at different seasons

\begin{tabular}{|c|c|c|c|c|c|c|c|c|}
\hline \multirow[b]{2}{*}{ Item } & \multirow[b]{2}{*}{ Time } & \multicolumn{4}{|c|}{ Season $^{1}$} & \multicolumn{3}{|c|}{$P$-value ${ }^{2}$} \\
\hline & & Winter & Spring & Summer & Autumn & Season & $\begin{array}{c}\text { Season } \\
\times \text { age }\end{array}$ & $\begin{array}{c}\text { Season } \\
\times \text { THI }\end{array}$ \\
\hline \multirow[t]{2}{*}{ Fresh total motility, $\%$} & Spg & $83.5 \pm 3.7^{\mathrm{a}}$ & $83.2 \pm 3.7^{\mathrm{ab}}$ & $82.6 \pm 3.7^{\mathrm{ab}}$ & $82.3 \pm 3.7^{\mathrm{b}}$ & $*$ & $* * *$ & $*$ \\
\hline & $\mathrm{Col}$ & $79.7 \pm 3.8^{\mathrm{b}}$ & $84.2 \pm 3.7^{\mathrm{a}}$ & $80.9 \pm 3.9^{\mathrm{ab}}$ & $82.0 \pm 3.7^{\mathrm{a}}$ & $* * *$ & $* * *$ & NS \\
\hline \multirow{2}{*}{ Fresh normal morphology, $\%$} & Spg & - & - & - & - & NS & $* * *$ & $* * *$ \\
\hline & $\mathrm{Col}$ & $92.5 \pm 1.2^{\mathrm{b}}$ & $93.8 \pm 1.2^{\mathrm{a}}$ & $93.1 \pm 1.2^{\mathrm{ab}}$ & $93.4 \pm 1.2^{\mathrm{ab}}$ & $\dagger$ & $* * *$ & NS \\
\hline \multirow{2}{*}{ Total motility $3 \mathrm{~h}, \%$} & Spg & $41.8 \pm 1.2^{\mathrm{ab}}$ & $41.6 \pm 1.2^{\mathrm{b}}$ & $44.4 \pm 1.2^{\mathrm{a}}$ & $41.3 \pm 1.2^{\mathrm{b}}$ & $* * *$ & $* *$ & $*$ \\
\hline & Col & $42.2 \pm 1.2^{\mathrm{ab}}$ & $42.6 \pm 1.2^{\mathrm{ab}}$ & $44.2 \pm 1.2^{\mathrm{a}}$ & $40.6 \pm 1.1^{\mathrm{b}}$ & $* * *$ & NS & NS \\
\hline \multirow{2}{*}{ Progressive motility $0 \mathrm{~h}, \%$} & Spg & $46.1 \pm 0.8^{\mathrm{ab}}$ & $47.1 \pm 0.8^{\mathrm{ab}}$ & $47.8 \pm 0.8^{\mathrm{a}}$ & $46.4 \pm 0.8^{\mathrm{b}}$ & $*$ & $* *$ & NS \\
\hline & $\mathrm{Col}$ & $46 \pm 0.9^{\mathrm{ab}}$ & $47.6 \pm 0.8^{\mathrm{a}}$ & $47.8 \pm 0.8^{\mathrm{a}}$ & $46 \pm 0.8^{\mathrm{b}}$ & ** & NS & NS \\
\hline \multirow[t]{2}{*}{ Progressive motility $3 \mathrm{~h}, \%$} & Spg & $35.9 \pm 1.1^{\mathrm{ab}}$ & $35.5 \pm 1.1^{\mathrm{b}}$ & $38.2 \pm 1.1^{\mathrm{a}}$ & $35.6 \pm 1.1^{\mathrm{b}}$ & $* * *$ & $* *$ & $*$ \\
\hline & $\mathrm{Col}$ & $36.3 \pm 1.1^{\mathrm{ab}}$ & $36.5 \pm 1.1^{\mathrm{ab}}$ & $38.0 \pm 1.1^{\mathrm{a}}$ & $35.1 \pm 1.0^{\mathrm{b}}$ & $* * *$ & NS & NS \\
\hline Normal morphology 0 h, \% & Spg & -3 & & & & NS & NS & NS \\
\hline 56-d Nonreturn rate, $\%$ & Col & - & - & - & - & NS & NS & NS \\
\hline
\end{tabular}

${ }^{\mathrm{a}-\mathrm{c}}$ Values with different superscripts in the same row are significantly different $(P \leq 0.05)$.

${ }^{1} \mathrm{LSM} \pm \mathrm{SEM}$ of each season for all of the variables at semen spermatogenesis (Spg) and collection (Col) time.

${ }^{2} P$-values of the effect of season and the interactions between season and age of the bull (months), and season and temperature-humidity index (THI) for all of the variables at semen spermatogenesis and collection time.

${ }^{3}$ No significant differences between different seasons; therefore, season was not included in the model.

$0 \leq * * * \leq 0.001<* * \leq 0.01<* \leq 0.05<\dagger \leq 0.1<\mathrm{NS} \leq 1$.

sperm collected in winter compared with summer. In their study, CASA was also performed immediately after thawing and after $3 \mathrm{~h}$ of incubation. However, unlike our analysis, they compared sperm quality of 5 Holstein-Friesian bulls collected in winter versus summer under subtropical conditions. Therefore, the differences observed may be due to the large variation of conditions in climatic zones.

\section{Interactions of Season with the Age of the Bull and the THI}

More significant interactive effects were observed in the variables at spermatogenesis compared with collection time (Tables 1 and 2). Moreover, the interaction between season and THI at collection time had more of an effect on fresh sperm of older bulls, whereas the same interaction at spermatogenesis time had more of an effect on frozen sperm of both young and older bulls. Therefore, we infer that THI compromises the resistance to cryopreservation of the sperm cells that are in meiosis. Studies in scrotal insulation have been relevant to determine the effect of heat stress on the developing sperm cells. Minor defects have been observed on sperm cells that were located in the epididymis at the time of the insult; however, most detrimental effects were observed during meiotic stages, indicating that heat stress is more prejudicial for developing germ cells than for mature sperm (Rahman et al., 2011). Moreover, FuerstWaltl et al. (2006) also observed that the temperature effect before semen collection was greater than on the day of collection. In a previous study, we observed a decreased sperm viability and a tendency toward higher reactive oxygen species production after a high THI period in summer compared with a low THI period in early spring. Moreover, in vitro fertility was reduced in sperm collected at a high THI period compared with the samples collected at a low THI period (LlamasLuceño et al., 2020).

The response to elevated THI at different seasons varied according to the age group. In all of the significant interactions between season and THI (collection or spermatogenesis), all of the outcome variables in young bulls tended to decrease as the THI increased in summer, except for normal morphology at $3 \mathrm{~h}$ if the THI was high at collection time. In contrast, all of the variables in older bulls tended to decrease as the THI (collection or spermatogenesis) increased in autumn, except for motility of fresh sperm at collection time. A similar effect is also visible in cows, as a long-lasting effect of heat stress affects the ovarian pool of oocytes and, consequently, the conception rate remains low during autumn (Ron et al., 1984; Badinga et al., 1985; Roth et al., 2001). However, in our study, 
the interaction between season THI (collection or spermatogenesis) did not affect the NRR $56 \%$ of young and older bulls.

Frozen semen is widely used for AI in cattle. Out of the millions of sperm cells that are deposited in the female genital tract, only a few hundred reach the oviduct several hours after, as the hostile female genital tract eliminates most of the sperm cells (Yanagimachi, 1994). In heifers, sperm cells deposited at the cervix and uterus need 6 to $8 \mathrm{~h}$ to reach the utero-tubal junction after AI (Wilmut and Hunter, 1984). Therefore, determining the quality of the sperm a few hours after thawing would be a better approach to evaluate the quality of the sperm that could potentially survive in vivo. Although no differences were observed between seasons when spermatogenesis occurred, the increase of THI during spermatogenesis in autumn produced a pronounced decrease (Figure 1) of total motility, progressive motility, and normal morphology $3 \mathrm{~h}$ after thawing $(P<0.05$, except normal morphology of older bulls: $P=0.07)$ in both young bulls $(40,34$, and $82 \%$ at THI 80 compared with 47, 40, and $97 \%$ at THI 30 , respectively) and older bulls $(36,33$, and $83 \%$ at THI 80 compared with 54, 47, and $97 \%$ at THI 30, respectively).

In young bulls, total motility of fresh and frozen $(0 \mathrm{~h})$ sperm, and morphology of fresh sperm, were on average higher $(P<0.001)$ when spermatogenesis occurred in summer, as well as total motility $0 \mathrm{~h}$ after thawing sperm of older bulls $(P<0.001)$. This increase in the average values was due to an increase of motility and morphology percentages when spermatogenesis occurred at a low THI (30) in summer (Figure 1A). However, the percentage of motility at a high THI (80) in summer was similar to the percentage at a high THI in winter and spring. Therefore, we confirmed that a high THI during spermatogenesis did not have an additional negative effect on motility in summer, as it could be expected, but a low THI in the summer had a positive effect on the sperm cells that were in meiosis. However, at $3 \mathrm{~h}$ after thawing, the average sperm motility was not significantly higher than when spermatogenesis occurred in summer (Tables 1 and 2), and the motility at a low THI (30) was similar in winter and spring (Figure 1B).

Regardless of the season, motility, progressive motility, and normal morphology of fresh and frozen sperm 0 and $3 \mathrm{~h}$ after thawing increased as the age of the bull increased in young bulls, probably due to the fact that sexual maturity had been reached. In most cases, this increase was higher in autumn compared with other seasons. However, characteristics of fresh sperm (at collection and spermatogenesis) and frozen sperm (at collection) were on average significantly lower in autumn compared with other seasons (Table 1). In contrast, all variables decreased as the age of the bull increased in older bulls, with the exception of autumn, when, in some cases, total and progressive motility remained constant. However, the interaction between season (collection or spermatogenesis) and age did not show significant effects on the NRR $56 \%$ of young and older bulls.

\section{Age and THI Effects on Sperm Characteristics and Nonreturn Rates}

In general, age had a positive effect on the sperm quality of young bulls and a negative effect on older bulls (Tables 3 and 4 ). The youngest bulls may not yet have reached sufficient sperm quality, whereas bulls around 35 mo old had a better overall sperm quality. These findings agree with other authors, which described low semen production values in peripubertal bulls aged less than 12 mo (Al-Kanaan et al., 2015; Murphy et al., 2018), as puberty occurs at approximately 9 to 11 mo of age in Holstein-Friesian bulls (Harstine et al., 2015; Byrne et al., 2017) and their reproductive capacity increases for several years (Amann, 1983). However, as the bulls became older, the sperm motility and morphology decreased. This decrease can be due to a decrease of antioxidant protection in the semen upon aging and, consequently, an increase in oxidative damage to sperm cells, which is known to alter sperm movement (Carreira et al., 2017). As a consequence, NRR56\% showed a tendency $(P=0.08)$ to decrease for every month of age increase (Table 4$)$. In contrast, the age of older bulls had a positive effect on fresh motility, increasing sperm motility on the original scale $0.1 \%$ for every extra month of age. Moreover, THI did not have a significant effect on sperm motility of fresh sperm. Therefore, fresh sperm increased in quality as the age of the bull increased but compromised the resistance to cryopreservation of the sperm cells. Using fresh sperm from older bulls should be considered for AI whenever possible to overcome these lower NRR $56 \%$.

A positive effect of the THI at sperm collection was observed on fresh and frozen sperm of young bulls (Table 3). However, THI negatively affected meiotic sperm cells, reducing their cryoresistance. Moreover, the interaction between THI and age of young bulls significantly affected fresh and frozen sperm at collection time; however, when spermatogenesis occurred, a significant effect was only observed on frozen sperm.

On the other hand, frozen sperm from older bulls showed increased sensitivity to higher THI. A negative effect of THI at both semen collection and spermatogenesis time was observed on sperm quality variables. However, frozen sperm of older bulls was up to 3.8 
times more negatively affected by an increase in THI at the time of spermatogenesis compared with at the time of semen collection (Table 4). This suggested that THI had a smaller effect on the motility and morphology of mature sperm compared with meiotic cells. These findings agree with the study of Sabés-Alsina et al. (2019), which demonstrated that sperm quality variables are more likely to be correlated with climate factors 1 or 2 mo before semen collection than in the month of semen collection. For instance, at a THI of 80 at spermatogenesis, progressive motility of the oldest bulls (140 mo) decreased $39 \% 0 \mathrm{~h}$ after thawing and $22 \%$ in progressive motility $3 \mathrm{~h}$ after thawing compared with a THI of 30 (Figure $2 \mathrm{~A}$ and $\mathrm{B}$ ). However, this decrease produced by an elevated THI at spermatogenesis had no effect on the NRR $56 \%$.
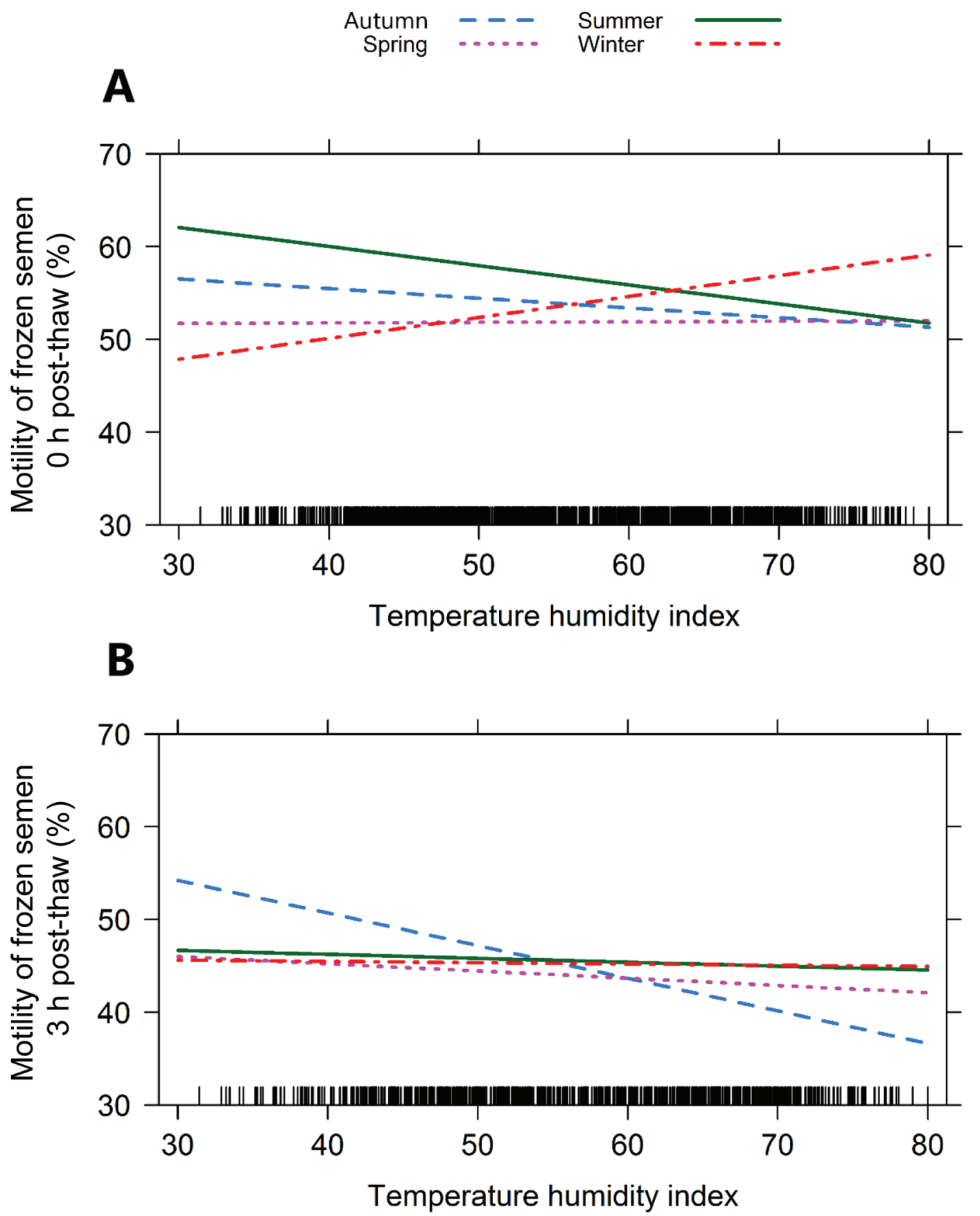

Figure 1. Interaction between season and temperature-humidity index (THI) at spermatogenesis on total motility of frozen semen 0 h (A) and $3 \mathrm{~h}(\mathrm{~B})$ after thawing of semen from older ( $\geq 36$ mo old) dairy bulls. The bottom vertical black lines represent the density of samples in the data distributed on the $\mathrm{x}$-axis. 
Table 3. Comparative effect between age of the bull and temperature-humidity index (THI) on total motility and normal morphology of fresh sperm, total motility, progressive motility, and normal morphology of frozen sperm 0 and $3 \mathrm{~h}$ after thawing, and nonreturn rate $56 \mathrm{~d}$ after AI with semen from young $\left(<36\right.$ mo old) dairy bulls ${ }^{1}$

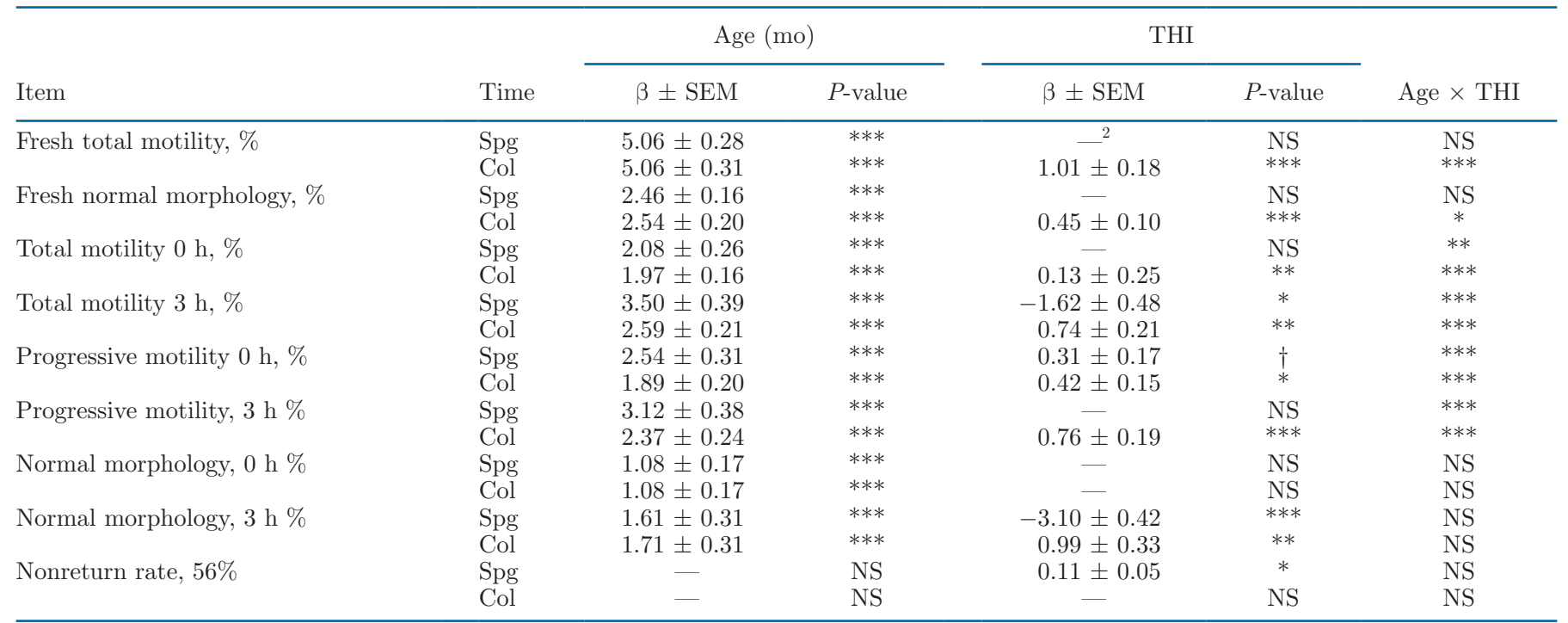

${ }^{1}$ Estimate effect $(\beta)$ represents the response of each variable $(\%)$ to every unit increase of age or THI. $P$-values of the effect of the age of the bull, THI, and the interaction between the age and the THI for all the variables at spermatogenesis (Spg) and semen collection (Col) time. The age of the bull and the THI were used as covariates after re-scaling to a mean of 0 and SD of 1.

${ }^{2}$ No significant effect.

$0 \leq * * * \leq 0.001<* * \leq 0.01<* \leq 0.05<\dagger \leq 0.1<\mathrm{NS} \leq 1$.

In contrast, older bulls showed a tendency $(P=0.06)$ toward reduced NRR56\% when semen was collected at a period of high THI. For instance, older bulls had
$2 \%$ less NRR $56 \%$ at a THI of 60 compared with the youngest bulls of the group (36 mo old), $3 \%$ less at a THI of 70 , and $4 \%$ less at a THI of 80 (Figure 3 ). The

Table 4. Comparative effect between age of the bull and temperature-humidity index (THI) on total motility and normal morphology of fresh sperm, total motility, progressive motility and normal morphology of frozen sperm 0 and $3 \mathrm{~h}$ after thawing, and nonreturn rate $56 \mathrm{~d}$ after artificial insemination with semen from older ( $\geq 36$ mo old) dairy bulls ${ }^{1}$

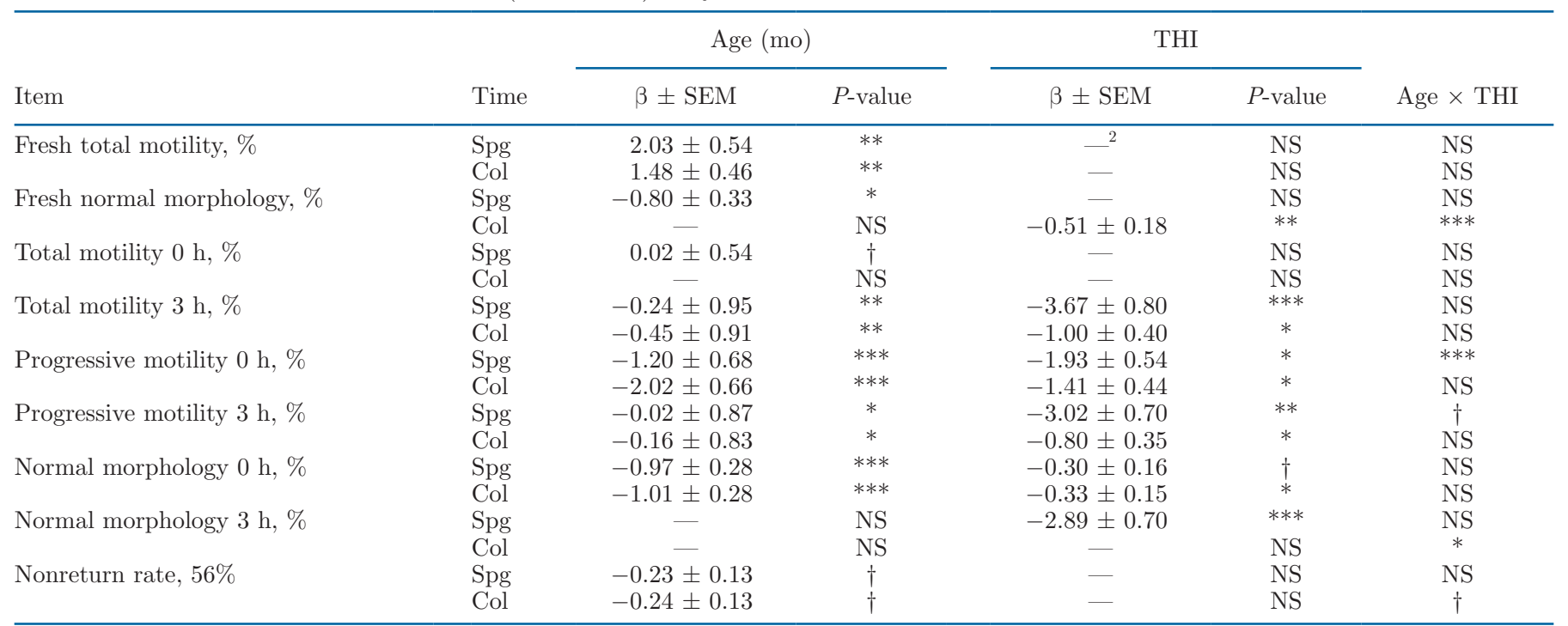

${ }^{1}$ Estimate effect $(\beta)$ represents the response of each variable (\%) to every unit increase of age or THI. $P$-values of the effect of the age of the bull, THI, and the interaction between the age and the THI for all the variables at spermatogenesis (Spg) and semen collection (Col) time. The age of the bull and the THI were used as covariates after re-scaling to a mean of 0 and SD of 1.

${ }^{2}$ No significant effect.

$0 \leq{ }^{* * *} \leq 0.001<{ }^{* *} \leq 0.01<* \leq 0.05<\dagger \leq 0.1<\mathrm{NS} \leq 1$. 


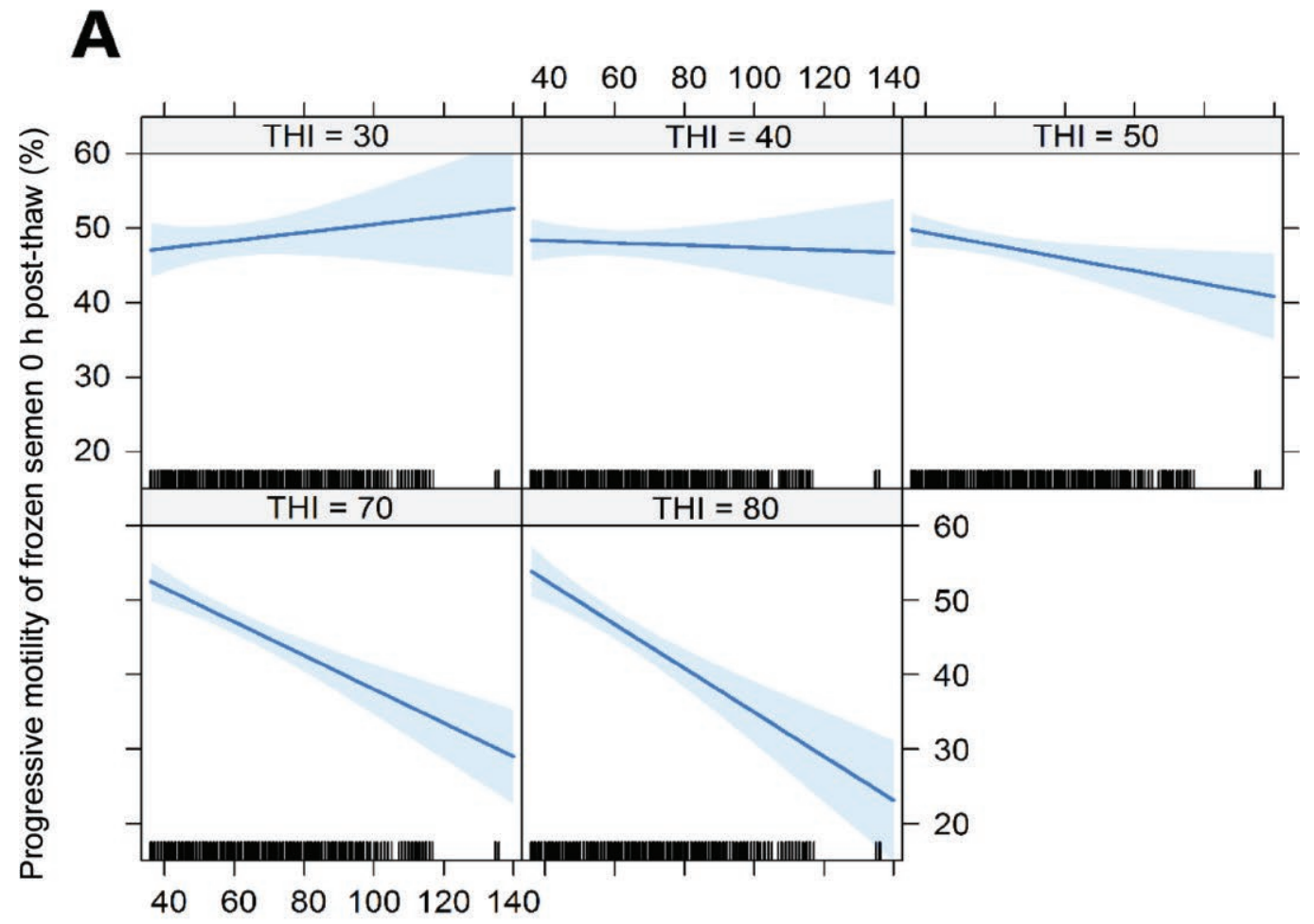

B

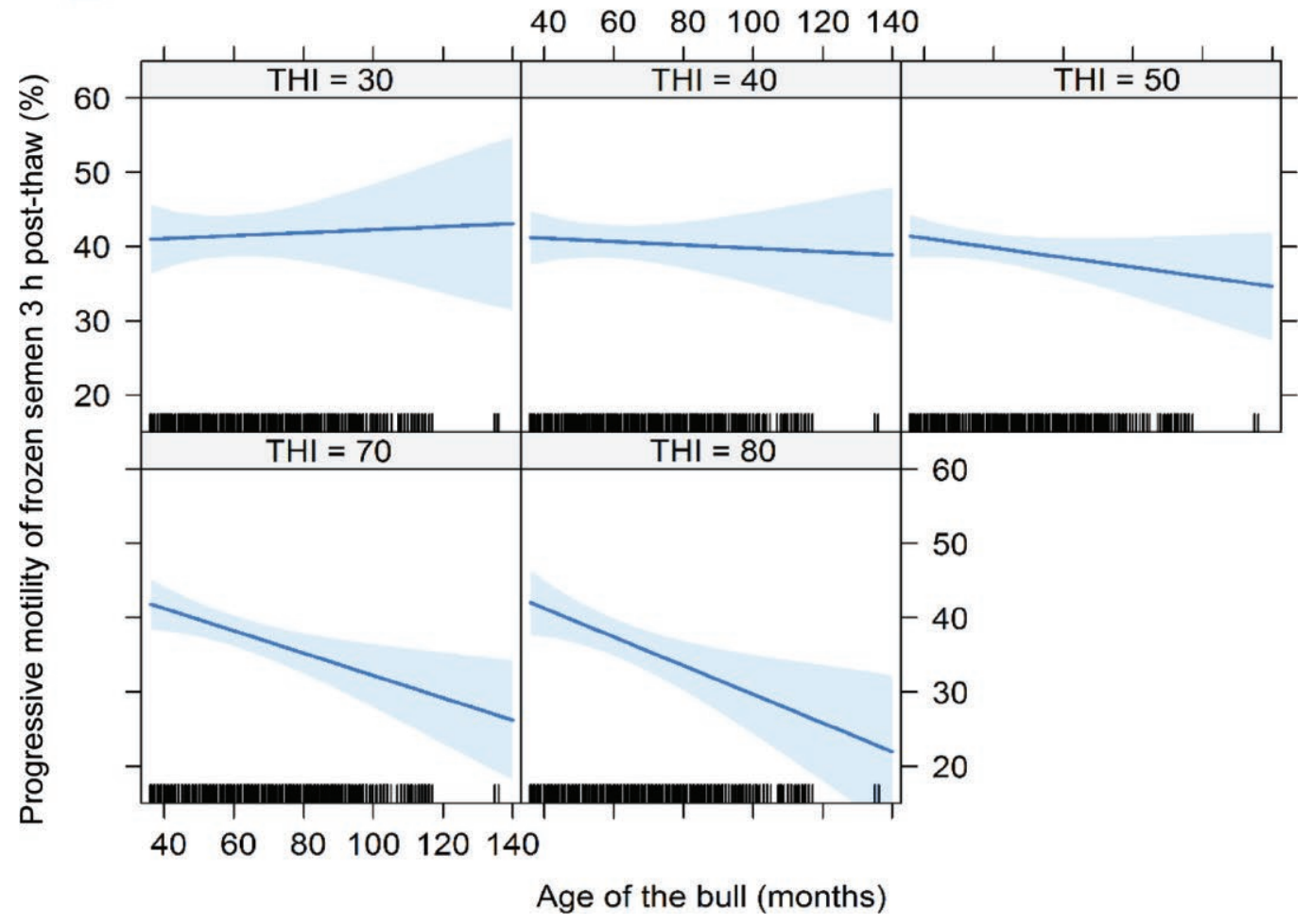

Figure 2. Plot of the effect of the interaction between the age of the bull (months) and temperature-humidity index (THI) at the time of spermatogenesis on the progressive motility from older ( $\geq 36$ mo old) dairy bulls at $0 \mathrm{~h}(\mathrm{~A})$ and $3 \mathrm{~h}$ after thawing (B). Interaction at THI of 30 , $40,50,70$, and 80 , automatically generated with the estimates of our model. The dark blue line represents the estimated average value and the light blue band represents the $95 \%$ CI. The bottom vertical black lines represent the density of samples in the data distributed on the x-axis. 


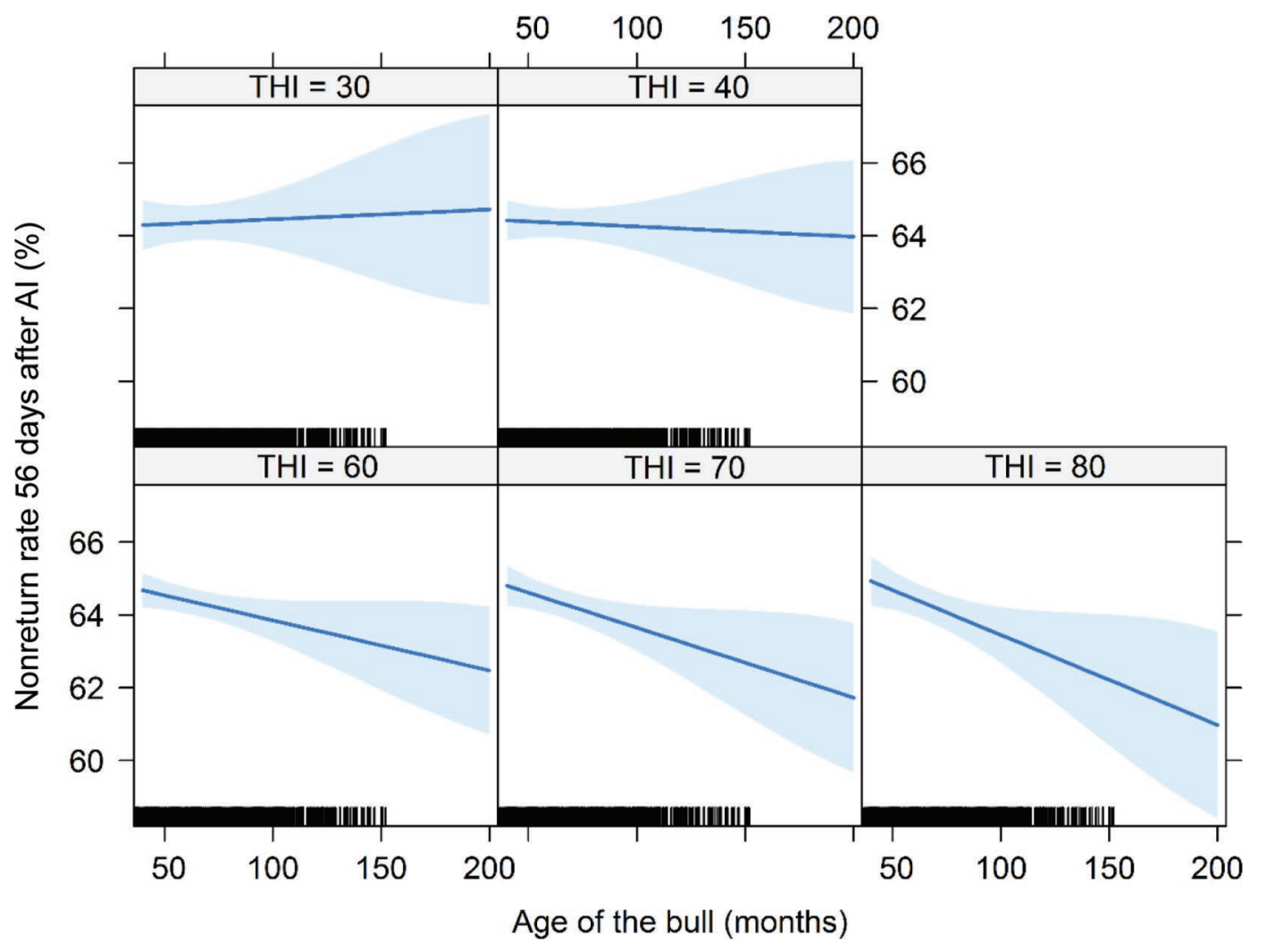

Figure 3. Plot of the effect of the interaction between the age of the bull (months) and temperature-humidity index (THI) at the time of semen collection on the nonreturn rates $56 \mathrm{~d}$ after AI. Interaction at THI of 30, 40,60,70, and 80, automatically generated with the estimates of our model. The dark blue line represents the estimated average value and the light blue band represents the $95 \%$ CI. The bottom vertical black lines represent the density of samples in the data distributed on the x-axis.

sperm cells used for AI were located at the epididymis when they were affected by a high THI. The epididymis is a specialized organ where sperm cells are matured and gain the ability to move and fertilize the oocyte (Yanagimachi, 1994). This is achieved due to the content of the epididymal milieu (lipids, proteins, ions, enzymes, and hormones) that induce changes in plasma membrane, acrosomal membrane, and nucleus of the sperm cells. As observed in rodents, cryptepididymal males are fertile (Bedford, 1978, 2015); however, the epididymal transportation, storage capacity, and the ionic and protein profile of the epididymal fluid was altered (Foldesy and Bedford, 1982; Wong et al., 1982; Esponda and Bedford, 1986; Regalado et al., 1993). Therefore, a stress applied to the epididymis might lead to sperm maturation failure which, consequently, might cause poor sperm-oocyte recognition and lower fertility. However, the NRR $56 \%$ decrease in cattle was low (up to 4\%). Therefore, the effect of high THI in temperate regions is not as alarming for the reproductive performance of bulls as it is in cows. However, this decrease can contribute to a generally lower NRR56\% when cows are inseminated at high THI as an addi- tional effect. Moreover, it is clear that due to climate change, the tendency of the meteorological conditions is to have more hot days throughout the year and more extreme climatic conditions, which may have a big impact on animal production (both males and females), as rising temperatures affect animal physiology, including loss of appetite, decreased growth rate, decreased milk and meat production, reduction of reproductive performance, and increased sensitivity to diseases (reviewed by Silanikove and Koluman, 2015). As a consequence, the availability of food for human consumption will considerably decline, causing important economic losses.

\section{CONCLUSIONS}

Results demonstrated that climatic conditions compromise not only sperm quality but also dairy bull fertility. We demonstrated that THI is an important metric that should be used, together with season, when assessing the effect of heat stress, even in temperate zones. Moreover, climatic conditions affect spermatogenic and mature sperm cells differently. High THI affected the cryotolerance of meiotic sperm cells. Moreover, older 
bulls exhibited increased sensitivity to THI, showing a 0.5 to 3 times larger negative effect on sperm quality at the time of spermatogenesis compared with semen collection. However, this study was limited to motility of sperm cells, their morphological evaluation, and AI trials. Therefore, further research should be considered to contribute to expand the knowledge of the reproductive physiology of dairy bulls under heat stress conditions.

\section{ACKNOWLEDGMENTS}

The authors are grateful to Andrés Carrasco (Byteflies, Antwerp, Belgium), Clio Maicas (University College Dublin, Ireland), and Hadi Atashi (Ghent University, Belgium) for their support in the statistical analysis, and Katrien Smits (Ghent University) for her assistance. This project was funded by European Union, Horizon 2020 Marie Sklodowska-Curie Action, REPBIOTECH 675526. The data set used for this research was based on the results of straws produced from ejaculates of bulls located at the centers of CRV (CRV B.V., Arnhem, the Netherlands). The authors declare no conflicts of interest.

\section{REFERENCES}

Al-Kanaan, A., S. König, and K. Brügemann. 2015. Effects of heat stress on semen characteristics of Holstein bulls estimated on a continuous phenotypic and genetic scale. Livest. Sci. 177:15-24. https://doi.org/10.1016/j.livsci.2015.04.003.

Alves, M. B., A. F. Andrade, R. P. Arruda, L. Batissaco, S. A. FlorezRodriguez, B. M. Oliveira, M. A. Torres, R. Lanconi, G. M. Ravagnani, R. R. Prado Filho, V. S. Vellone, J. D. Losano, C. R. Franci, M. Nichi, and E. C. Celeghini. 2016. Recovery of normal testicular temperature after scrotal heat stress in rams assessed by infrared thermography and its effects on seminal characteristics and testosterone blood serum concentration. Theriogenology 86:795-805.e2. https://doi.org/10.1016/j.theriogenology.2016.02.034.

Amann, R. P. 1983. Endocrine changes associated with onset of spermatogenesis in Holstein bulls. J. Dairy Sci. 66:2606-2622. https:// doi.org/10.3168/jds.S0022-0302(83)82135-3.

Armstrong, D. V. 1994. Heat stress interaction with shade and cooling. J. Dairy Sci. 77:2044-2050. https://doi.org/10.3168/jds.S0022 -0302(94)77149-6.

Badinga, L., R. J. Collier, W. W. Thatcher, and C. J. Wilcox. 1985. Effects of climatic and management factors on conception rate of dairy cattle in subtropical environment. J. Dairy Sci. 68:78-85. https://doi.org/10.3168/jds.S0022-0302(85)80800-6.

Barth, A. D., L. F. C. Brito, and J. P. Kastelic. 2008. The effect of nutrition on sexual development of bulls. Theriogenology 70:485-494. https://doi.org/10.1016/j.theriogenology.2008.05.031.

Bates, D., M. Mächler, B. Bolker, and S. Walker. 2015. Fitting linear mixed-effects models using lme4. J. Stat. Softw. 67:1-48. https:// doi.org/10.18637/jss.v067.i01.

Bedford, J. M. 1978. Influence of abdominal temperature on epididymal function in the rat and rabbit. Am. J. Anat. 152:509-521. https://doi.org/10.1002/aja.1001520405.

Bedford, J. M. 2015. Human spermatozoa and temperature: The elephant in the room. Biol. Reprod. 93. https://doi.org/10.1095/ biolreprod.115.130658.

Brito, L. F. C., A. E. D. F. Silva, L. H. Rodrigues, F. V. Vieira, L. A. G. Deragon, and J. P. Kastelic. 2002a. Effect of age and genetic group on characteristics of the scrotum, testes and testicular vascular cones, and on sperm production and semen quality in AI bulls in Brazil. Theriogenology 58:1175-1186. https://doi.org/10 .1016/S0093-691X(02)00921-4.

Brito, L. F. C., A. E. D. F. Silva, L. H. Rodrigues, F. V. Vieira, L. A. G. Deragon, and J. P. Kastelic. 2002b. Effects of environmental factors, age and genotype on sperm production and semen quality in Bos indicus and Bos taurus AI bulls in Brazil. Anim. Reprod. Sci. 70:181-190. https://doi.org/10.1016/S0378-4320(02)00009-X.

Byrne, C. J., S. Fair, A. M. English, C. Urh, H. Sauerwein, M. A. Crowe, P. Lonergan, and D. A. Kenny. 2017. Effect of breed, plane of nutrition and age on growth, scrotal development, metabolite concentrations and on systemic gonadotropin and testosterone concentrations following a GnRH challenge in young dairy bulls. Theriogenology 96:58-68. https://doi.org/10.1016/j theriogenology.2017.04.002.

Carreira, J. T., J. T. Trevizan, I. R. Carvalho, B. Kipper, L. H. Rodrigues, C. Silva, S. H. V. Perri, J. R. Drevet, and M. B. Koivisto. 2017. Does sperm quality and DNA integrity differ in cryopreserved semen samples from young, adult, and aged Nellore bulls? Basic Clin. Androl. 27:12. https://doi.org/10.1186/s12610-017 -0056-9.

De Rensis, F., I. Garcia-Ispierto, and F. López-Gatius. 2015. Seasonal heat stress: Clinical implications and hormone treatments for the fertility of dairy cows. Theriogenology 84:659-666. https://doi .org/10.1016/j.theriogenology.2015.04.021.

Dikmen, S., and P. J. Hansen. 2009. Is the temperature-humidity index the best indicator of heat stress in lactating dairy cows in a subtropical environment? J. Dairy Sci. 92:109-116. https://doi .org/10.3168/jds.2008-1370.

Environmental Data Compendium. 2016. Temperature trends: The Netherlands and worldwide, 1906-2015. Accessed Aug. 8, 2019. https://www.clo.nl/en/indicators/en0226-temperature-trends-the -netherlands-and-worldwide.

Esponda, P., and J. M. Bedford. 1986. The influence of body temperature and castration on the protein composition of fluid in the rat cauda epididymidis. J. Reprod. Fertil. 78:505-514. https://doi .org/10.1530/jrf.0.0780505.

Foldesy, R. G., and J. M. Bedford. 1982. Biology of the scrotum. I. Temperature and androgen as determinants of the sperm storage capacity of the rat cauda epididymidis. Biol. Reprod. 26:673-682. https://doi.org/10.1095/biolreprod26.4.673.

Fuerst-Waltl, B., H. Schwarzenbacher, C. Perner, and J. Sölkner. 2006. Effects of age and environmental factors on semen production and semen quality of Austrian Simmental bulls. Anim. Reprod. Sci. 95:27-37. https://doi.org/10.1016/j.anireprosci.2005.09.002.

García-Ispierto, I., F. López-Gatius, G. Bech-Sabat, P. Santolaria, J. L. Yániz, C. Nogareda, F. De Rensis, and M. López-Béjar. 2007. Climate factors affecting conception rate of high producing dairy cows in northeastern Spain. Theriogenology 67:1379-1385. https:/ /doi.org/10.1016/j.theriogenology.2007.02.009.

Goddard, M. E., and B. J. Hayes. 2007. Genomic selection. J. Anim. Breed. Genet. 124:323-330. https://doi.org/10.1111/j.1439-0388 .2007.00702.x

Hansen, P. J. 2009. Effects of heat stress on mammalian reproduction. Philos. Trans. R. Soc. Lond. B Biol. Sci. 364:3341-3350. https:// doi.org/10.1098/rstb.2009.0131.

Harstine, B. R., M. Maquivar, L. A. Helser, M. D. Utt, C. Premanandan, J. M. DeJarnette, and M. L. Day. 2015. Effects of dietary energy on sexual maturation and sperm production in Holstein bulls. J. Anim. Sci. 93:2759-2766. https://doi.org/10.2527/jas .2015-8952.

Haugan, T., O. Reksen, Y. T. Gröhn, E. Kommisrud, E. Ropstad, and E. Sehested. 2005. Seasonal effects of semen collection and artificial insemination on dairy cow conception. Anim. Reprod. Sci. 90:57-71. https://doi.org/10.1016/j.anireprosci.2005.02.002.

Herbut, P., and S. Angrecka. 2018. Relationship between THI level and dairy cows' behaviour during summer period. Ital. J. Anim. Sci. 17:226-233. https://doi.org/10.1080/1828051X.2017.1333892.

KNMI (Koninklijk Nederlands Meteorologisch Instituut). 2018. Klimatologie-Informatie over weer in het verleden. Accessed Aug. 1, 2018. https://www.knmi.nl/nederland-nu/klimatologie. 
Köppen, W. 1931. Klimakarte der Erde. 2nd ed. Grundriss der Klimakunde, Berlin, Germany.

Llamas Luceño, N., D. de Souza Ramos Angrimani, L. de Cássia Bicudo, K. J. Szymańska, M. Van Poucke, K. Demeyere, E. Meyer, L. Peelman, E. Mullaart, M. L. W. J. Broekhuijse, and A. Van Soom. 2020. Exposing dairy bulls to high temperature-humidity index during spermatogenesis compromises subsequent embryo development in vitro. Theriogenology 141:16-25. https://doi.org/10.1016/ j.theriogenology.2019.08.034.

Mader, T. L., M. S. Davis, and T. Brown-Brandl. 2006. Environmental factors influencing heat stress in feedlot cattle. J. Anim. Sci. 84:712-719. https://doi.org/10.2527/2006.843712x.

Malama, E., Y. Zeron, F. Janett, M. Siuda, Z. Roth, and H. Bollwein. 2017. Use of computer-assisted sperm analysis and flow cytometry to detect seasonal variations of bovine semen quality. Theriogenology 87:79-90. https://doi.org/10.1016/j.theriogenology.2016.08 .002 .

Menegassi, S. R. O., G. R. Pereira, C. Bremm, C. Koetz Jr., F. G. Lopes, E. C. Fiorentini, C. McManus, E. A. Dias, M. K. da Rocha, R. B. Lopes, and J. O. J. Barcellos. 2016. Effects of ambient air temperature, humidity, and wind speed on seminal traits in Braford and Nellore bulls at the Brazilian Pantanal. Int. J. Biometeorol. 60:1787-1794. https://doi.org/10.1007/s00484-016-1167-2.

Meyerhoeffer, D. C., R. P. Wettemann, S. W. Coleman, and M. E. Wells. 1985. Reproductive criteria of beef bulls during and after exposure to increased ambient temperature. J. Anim. Sci. 60:352357. https://doi.org/10.2527/jas1985.602352x.

Murphy, E. M., A. K. Kelly, C. O’Meara, B. Eivers, P. Lonergan, and S. Fair. 2018. Influence of bull age, ejaculate number, and season of collection on semen production and sperm motility parameters in Holstein Friesian bulls in a commercial artificial insemination centre. J. Anim. Sci. 96:2408-2418. https://doi.org/10.1093/jas/ sky130.

NASA (National Aeronautics and Space Administration). 2019. Global climate change. Accessed Aug. 8, 2019. https://climate.nasa.gov/

Pachauri, R., A. Reisinger, and Core Writing Team. 2007. AR4 Climate Change 2007: Synthesis Report. Contribution of Working Groups I, II and III to the Fourth Assessment Report of the Intergovernmental Panel on Climate Change. IPCC, Geneva, Switzerland.

R Core Team. 2013. R: A language and environment for statistical computing. R Foundation for Statistical Computing, Vienna, Austria. http://www.R-project.org/.

Rahman, M. B., L. Vandaele, T. Rijsselaere, D. Maes, M. Hoogewijs, A. Frijters, J. Noordman, A. Granados, E. Dernelle, M. Shamsuddin, J. J. Parrish, and A. Van Soom. 2011. Scrotal insulation and its relationship to abnormal morphology, chromatin protamination and nuclear shape of spermatozoa in Holstein-Friesian and Belgian Blue bulls. Theriogenology 76:1246-1257. https://doi.org/10 .1016/j.theriogenology.2011.05.031.

Regalado, F., P. Esponda, and A. Nieto. 1993. Temperature and androgens regulate the biosynthesis of secretory proteins from rabbit cauda epididymidis. Mol. Reprod. Dev. 36:448-453. https://doi .org/10.1002/mrd.1080360407.

Romanello, N., J. de Brito Lourenco Junior., W. Barioni Junior., F. Z. Brandao, C. R. Marcondes, J. R. M. Pezzopane, M. H. de Andrade Pantoja, D. Botta, A. Giro, A. B. B. Moura, A. do Nascimento Barreto, and A. R. Garcia. 2018. Thermoregulatory responses and reproductive traits in composite beef bulls raised in a tropical climate. Int. J. Biometeorol. 62:1575-1586. https://doi.org/10.1007/ s00484-018-1557-8.

Ron, M., R. Bar-Anan, and G. R. Wiggans. 1984. Factors affecting conception rate of Israeli Holstein cattle. J. Dairy Sci. 67:854-860. https://doi.org/10.3168/jds.S0022-0302(84)81377-6.
Roth, Z., A. Arav, A. Bor, Y. Zeron, R. Braw-Tal, and D. Wolfenson. 2001. Improvement of quality of oocytes collected in the autumn by enhanced removal of impaired follicles from previously heat-stressed cows. Reproduction 122:737-744. https://doi.org/10 $.1530 /$ rep.0.1220737.

Sabés-Alsina, M., A. Johannisson, N. Lundeheim, M. Lopez-Bejar, and J. M. Morrell. 2017. Effects of season on bull sperm quality in thawed samples in northern Spain. Vet. Rec. 180:251. https://doi .org/10.1136/vr.103897.

Sabés-Alsina, M., N. Lundeheim, A. Johannisson, M. López-Béjar, and J. M. Morrell. 2019. Relationships between climate and sperm quality in dairy bull semen: A retrospective analysis. J. Dairy Sci. 102:5623-5633. https://doi.org/10.3168/jds.2018-15837.

Sailer, B. L., L. J. Sarkar, J. A. Bjordahl, L. K. Jost, and D. P. Evenson. 1997. Effects of heat stress on mouse testicular cells and sperm chromatin structure. J. Androl. 18:294-301. https://doi .org/10.1002/j.1939-4640.1997.tb01922.x.

Schefers, J. M., and K. A. Weigel. 2012. Genomic selection in dairy cattle: Integration of DNA testing into breeding programs. Anim. Front. 2:4-9. https://doi.org/10.2527/af.2011-0032.

Setchell, B. P. 1998. The Parkes lecture. Heat and the testis. J. Reprod. Fertil. 114:179-194. https://doi.org/10.1530/jrf.0.1140179.

Silanikove, N., and N. Koluman (Darcan). 2015. Impact of climate change on the dairy industry in temperate zones: Predications on the overall negative impact and on the positive role of dairy goats in adaptation to earth warming. Small Rumin. Res. 123:27-34. https://doi.org/10.1016/j.smallrumres.2014.11.005.

Thom, E. C. 1959. The discomfort index. Weatherwise 12:57-61. https: //doi.org/10.1080/00431672.1959.9926960.

van Oldenborgh, G. J., S. Drijfhout, A. Van Ulden, R. Haarsma, A. Sterl, C. Severijns, W. Hazeleger, and H. Dijkstra. 2009. Western Europe is warming much faster than expected. Clim. Past 5:1-12. https://doi.org/10.5194/cp-5-1-2009.

Wettemann, R., and B. Boehmer. 2014. Influence of heat stress on male fertility. Pages 257-263 in Proc. Applied Reproductive Strategies in Beef Cattle. Oklahoma State Research and Extension, Stillwater, OK.

Wilkanowska, A., and D. Kokoszyński. 2015. Effect of diet and physical activity of farm animals on their health and reproductive performance. Pages 159-171 in Handbook of Fertility. R. R. Watson, ed. Academic Press, San Diego, CA.

Wilmut, I., and R. H. Hunter. 1984. Sperm transport into the oviducts of heifers mated early in oestrus. Reprod. Nutr. Dev. 24:461-468. https://doi.org/10.1051/rnd:19840411.

Wong, P. Y., C. L. Au, and J. M. Bedford. 1982. Biology of the scrotum. II. Suppression by abdominal temperature of transepithelial ion and water transport in the cauda epididymidis. Biol. Reprod. 26:683-689. https://doi.org/10.1095/biolreprod26.4.683.

Yanagimachi, R. 1994. Mammalian fertilization. Pages 189-317 in The Physiology of Reproduction Vol. 1. E. Knobil and J. D. Neill, ed. Raven Press, New York, NY.

\section{ORCIDS}

Núria Llamas-Luceño @ https://orcid.org/0000-0002-9670-4680 Miel Hostens @ https://orcid.org/0000-0001-5376-976X Erik Mullaart @ https://orcid.org/0000-0001-9596-4985 Marleen Broekhuijse (ㄴ) https://orcid.org/0000-0002-1831-4011 Pat Lonergan @ https://orcid.org/0000-0001-5598-5044 